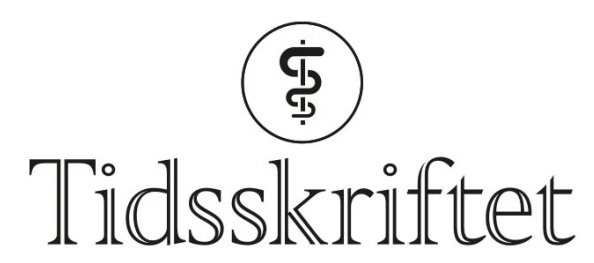

DEN NORSKE LEGEFORENING

\title{
Intramural gastrisk abscess
}

\author{
KORT KASUISTIKK
}

\section{SILJE BERGERSEN}

bergersensilje@gmail.com

Lungemedisinsk avdeling

St. Olavs hospital

Silje Bergersen er lege i spesialisering i lungesykdommer og i indremedisin.

Forfatteren har fylt ut ICMJE-skjemaet og oppgir ingen interessekonflikter.

\section{HANS MARTIN HOLDEN}

Avdeling for bildediagnostikk

Sykehuset Levanger

Hans Martin Holden er spesialist i radiologi og overlege.

Forfatteren har fylt ut ICMJE-skjemaet og oppgir ingen interessekonflikter.

\section{ØYSTEIN BRENNA}

Medisinsk avdeling Sykehuset Levanger

Øystein Brenna er ph.d., spesialist i indremedisin og i fordøyelsessykdommer og overlege. Forfatteren har fylt ut ICMJE-skjemaet og oppgir ingen interessekonflikter.

\section{EIVIND NESS-JENSEN}

Medisinsk avdeling Sykehuset Levanger og

HUNT forskningssenter

NTNU

Eivind Ness-Jensen er spesialist i indremedisin og i fordøyelsessykdommer, overlege og førsteamanuensis.

Forfatteren har fylt ut ICMJE-skjemaet og oppgir ingen interessekonflikter.

\section{Intramural gastrisk abscess er en sjelden, men alvorlig differensialdiagnose ved feber og magesmerter. $\mathrm{Vi}$ presenterer her et tilfelle hos en ung mann der CT og endoskopisk undersøkelse sammen med kliniske funn ga korrekt diagnose.}


En mann i 2o-årene ble innlagt akutt ved medisinsk avdeling grunnet feber og magesmerter. Foruten kronisk hepatitt B-infeksjon var han tidligere frisk og brukte ingen faste medikamenter. Symptomene hadde debutert med hodepine halvannen uke tidligere, mens han var på utenlandsreise i et asiatisk land. Etter hjemkomst og fire dager før innleggelsen tilkom hoste, feberfølelse og magesmerter. Som febersenkende og smertestillende hadde han tatt ibuprofen $400 \mathrm{mg}$ inntil fire ganger daglig uken før innleggelsen.

Ved undersøkelse i akuttmottaket var pasienten i god allmenntilstand, men hadde feber på $38,0^{\circ} \mathrm{C}$ (målt i øret) og epigastriesmerter. Smertene var konstante og sviende, med forverring ved mat- og væskeinntak. Han hadde ingen avføringsendringer, oppkast eller kvalme. Det forelå distinkt trykkømhet i epigastriet, men abdomen var bløt og uten palpable oppfylninger. Tarmlydene var normale. Orienterende blodprøver viste hemoglobin 15,5 g/dL (referanseområde 13,4-17,0), CRP $128 \mathrm{mg} / \mathrm{L}(<5)$ og leukocytter 13,4× $10^{9} / \mathrm{L}(4,1-9,8)$. Nyrefunksjon, elektrolytter, lever-/galleprøver samt funn på røntgen toraks og urinstiks var normale. Det ble tatt to sett blodkulturer. Hemofec var negativ.

Symptomene ble oppfattet som suspekt gastritt grunnet høyt inntak av ikke-steroide antiinflammatoriske midler (NSAID), og han fikk behandling med pantoprazol $40 \mathrm{mg}$ to ganger daglig peroralt. I tillegg mistenkte man infeksjon med ukjent fokus, men avventet antibiotika grunnet god allmenntilstand. På innleggelsesdag 3 steg CRP til $282 \mathrm{mg} / \mathrm{L}$. Det ble derfor samme dag gjennomført CT abdomen (figur 1), som påviste en $60 \times 35 \mathrm{~mm}$ intramural oppfylning prepylort i magesekken med flere lavattenuerende lokulamenter og perifer kontrastoppladning, forenlig med abscess eller malign prosess.

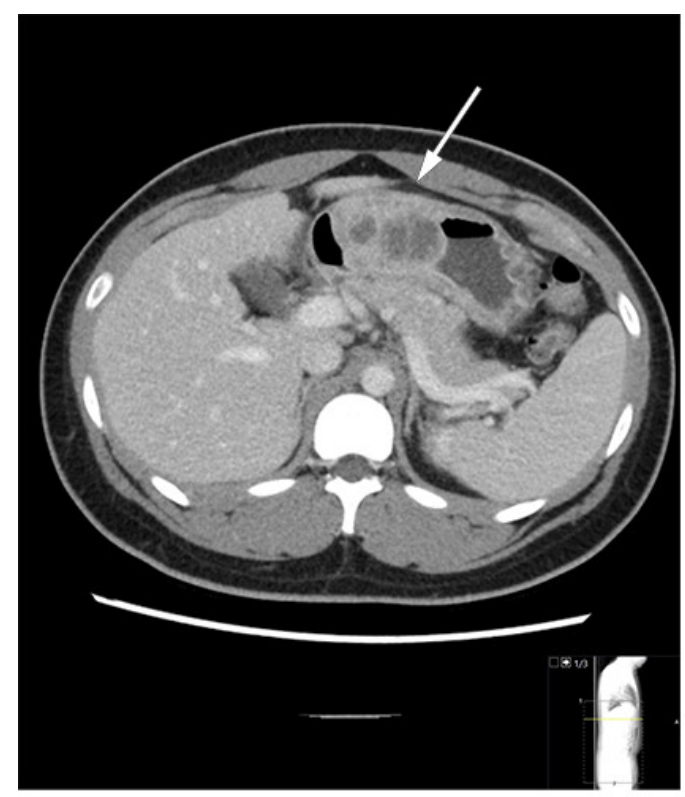

a

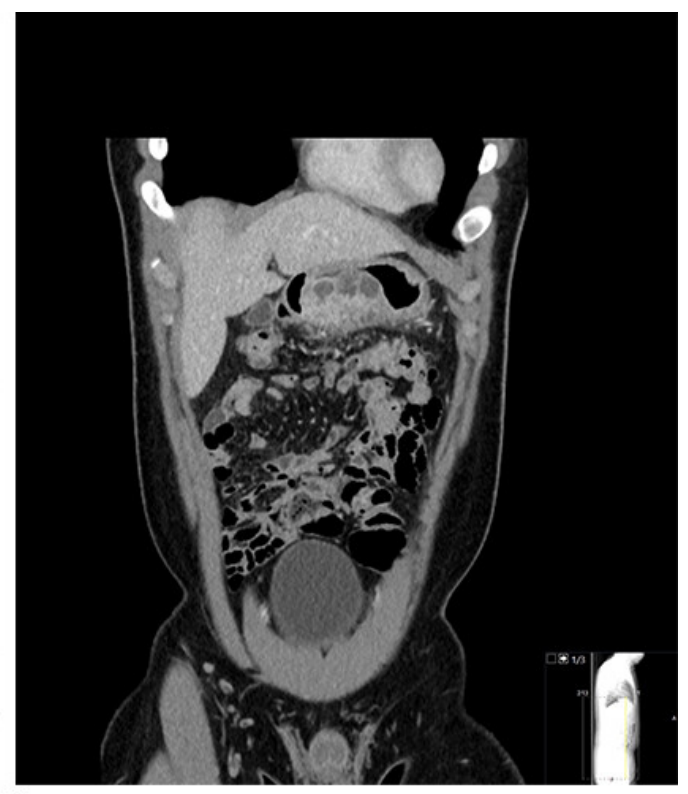

b

Figur 1 Transversale (a) og koronale (b) CT-snitt gjennom abdomen med intravenøs kontrastvæske og negativ peroral kontrastmarkering med vann viser multilokulær masse på curvatura major i antrum.

Ved gastroskopi fem dager etter innleggelsen fant man en submukøs, protruerende tumor som dekket hele majorsiden av antrum (figur 2a), tilsvarende CT-funnet. Det var noen mindre erosjoner over selve lesjonen, ellers normal mageslimhinne. Tumor ble punktert med nål gjennom endoskopet, hvorpå det tømte seg store mengder puss. Mistanken om intramural gastrisk abscess ble dermed styrket. Det ble tatt aspirat til mikroskopi og dyrkning samt slimhinnebiopsier fra lesjonen. 

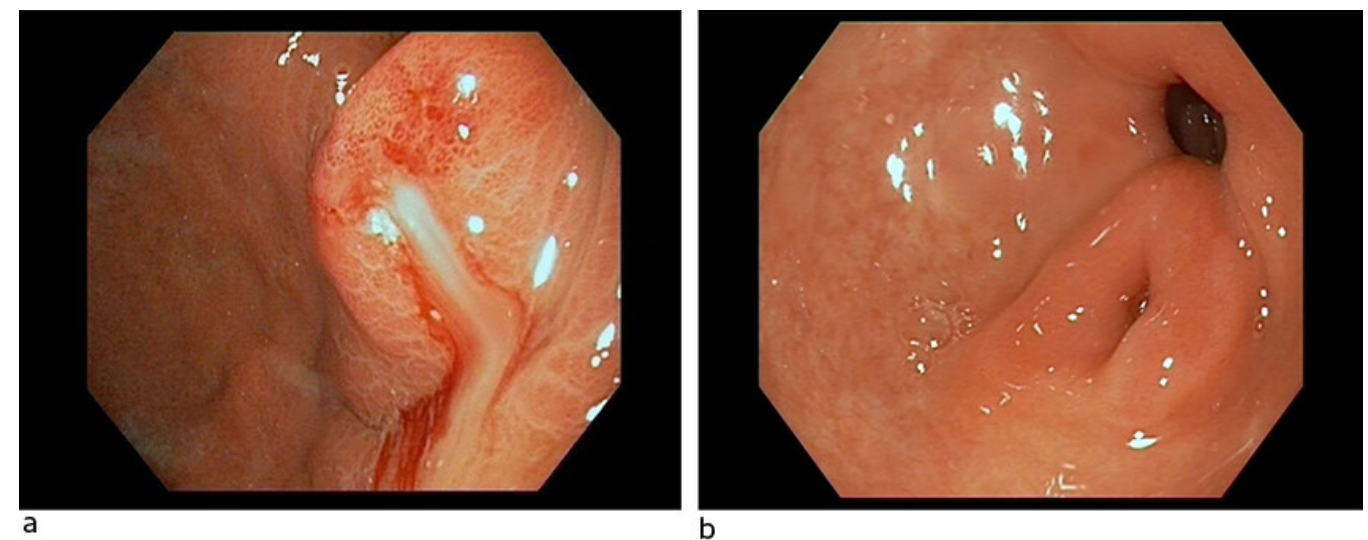

Figur 2 Gastroskopi. a) Man ser en stor submukøs tumor i antrum med flere små erosjoner og diffus rødme, der puss tømmes etter punksjon med nål gjennom endoskopet. b)

Kontroll fem måneder senere viser voll og defekt i slimhinnen tilsvarende lokalisasjonen til abscessen, for øvrig normale slimhinner.

Mikroskopi av pussekret viste grampositive kokker, ingen parasitter. Dyrkning viste rikelig vekst av Staphylococcus aureus, Neisseria subflava og Haemophilus parainfluenzae.

Polymerasekjedereaksjonstest (PCR) og dyrkning for tuberkulose var negative.

Slimhinnebiopsier viste uspesifikke betennelsesforandringer uten granulomer eller tegn til malignitet. PCR og dyrkning for Helicobacter pylori var negative. Hivtest var også negativ og blodkulturer uten vekst. Etter drenasje avtok magesmertene raskt, og infeksjonsprøvene normaliserte seg. Under oppholdet ble det tatt avføringsprøver, med sparsomt funn av cyster fra Giardia lamblia. Funnet ble ikke satt i relasjon til pasientens gastriske abscess. Man valgte å behandle med metronidazol-tabletter $400 \mathrm{mg}$ tre ganger daglig i sju dager. Den kliniske og biokjemiske tilfriskningen kom imidlertid før oppstart av metronidazol. Pasienten ble utskrevet uten restsymptomer etter ti dager. CT ventrikkel åtte uker senere bekreftet full regress av abscessforandringene, og kontroll med gastroskopi fem måneder senere viste vollformet defekt i slimhinnen, ellers normale funn (figur 2 b).

\section{Diskusjon}

Intramural gastrisk abscess er en sjelden og ofte feildiagnostisert tilstand, og det er kun et begrenset antall engelskspråklige kasuistikker som er publisert om temaet (1). Hos vår pasient mistenkte man gastritt ved innkomst. I vurderingen vektla man smertelokalisasjon og -karakter og inntak av et NSAID-middel, selv om dette ikke forklarte forhøyet CRP-verdi. Intramural gastrisk abscess er en form for suppurativ gastritt, karakterisert av en purulent inflammasjonsprosess i ventrikkelveggen. Om lag 5-15\% er som i dette tilfellet lokaliserte og med abscessdannelse, mens de øvrige er diffuse, ofte kalt flegmonøs gastritt (2). Vår pasient hadde følgelig en infeksiøs gastritt.

Patogenesen ved gastrisk abscess er ikke fullstendig klarlagt, men skyldes trolig direkte invasjon av bakterier gjennom skadd mukosa. Sekundær hematogen spredning er beskrevet (3). Årsaken til at tilstanden er så sjelden, kan bero på magesekkens rike blodtilførsel og den baktericide effekten av magesyre som beskytter mot purulent infeksjon (4). Predisponerende faktorer er høy alder, skade på mageslimhinnen (inkludert kronisk gastritt, fremmedlegeme, endoskopisk/kirurgisk skade, ventrikkelcancer og inntak av etsende stoffer), redusert syresekresjon, alkoholisme, diabetes mellitus og hivinfeksjon $(3,4$.$) . Helicobacter pylori kan gi kronisk pangastritt og aklorhydri. Antakelig vil kronisk H$. pylori-gastritt derfor kunne disponere for suppurativ gastritt (5). Av samme grunn vil bruk av protonpumpehemmere kunne disponere for tilstanden.

Det ble ikke påvist H. pylori eller andre risikofaktorer hos vår pasient. Vedrørende funn av G. lamblia hadde pasienten ikke typiske symptomer på giardiasis med diaré, og han hadde ikke vært i antatt endemisk område. Ca. 50 \% av rapporterte tilfeller i Norge er smittet på utenlandsreise, og langvarig bærerskap er vanlig (므). Det er oss bekjent ingen etablert 
sammenheng mellom giardiasis og gastrisk abscess, og vi mener det er overveiende sannsynlig at dette var asymptomatisk bærerskap uten relasjon til det aktuelle sykdomstilfellet.

Gastrisk abscessdannelse er oftest lokalisert til antrum. Tilstanden affiserer menn hyppigere enn kvinner (3:1) og hyppigst i alderen 30-6o år (7.). Det dominerende symptomet er epigastriesmerter. Ledsagende symptomer kan være kvalme, oppkast og feber. Smertelette fra liggende til sittende stilling (såkalte Deininger-tegn), og oppkast av rent puss er sykdomsspesifikke, men sjeldne tegn. Den vanligste mikrobielle agens er streptokokker, men også andre agens er beskrevet, blant annet stafylokokker, som illustrert her. Multimikrobiell flora er ikke uvanlig $(1,3)$. Abdominal CT vil ikke nødvendigvis kunne skille mellom abscess og malignitet. Endoskopisk ses en submukøs oppfylning som makroskopisk ikke kan differensieres fra gastrointestinale stromale tumorer. Abscessmistanken styrkes dersom det ved inspeksjon eller etter punksjon lekker ut puss (2). På bakgrunn av normale histopatologiske undersøkelser og komplett regress etter drenasje kunne vi konkludere med intramural gastrisk abscess.

Endoskopisk ultralyd kan gi nyttig bidrag, men ble ikke benyttet her. Typiske funn vil være lokalisert veggfortykkelse og en velavgrenset intramural masse med innhold av varierende ekkogenisitet $(\underline{2}, 7.7)$.

Lenge var kirurgisk reseksjon av hele eller deler av magesekken, kombinert med antibiotika, den anbefalte behandlingsformen ved denne typen abscesser. Imidlertid har endoskopisk diagnostikk og behandling i form av drenasje, med eller uten antibiotika, i stor grad erstattet kirurgi. Perkutan radiologisk veiledet drenasje er også beskrevet $(\underline{1}, \mathrm{z}$. .). Tidlig diagnose er avgjørende og kan forhindre unødvendig kirurgi eller alvorlige komplikasjoner, inkludert død ( $\underline{8})$.

Pasienten har gitt samtykke til at artikkelen blir publisert.

Artikkelen erfagfellevurdert.

\section{LITTERATUR}

1. Choong NWW, Levy MJ, Rajan E et al. Intramural gastric abscess: case history and review. Gastrointest Endosc 2003; 58: 627-9. [PubMed]

2. Chen Y, Han Y, Du J. Diagnostic challenges in differentiating intramural gastric abscess from gastric cancer: Two case reports. Medicine (Baltimore) 2018; 97: e12756. [PubMed][CrossRef]

3. Marcos WC, Petrini BG, Xavier RL et al. Gastric wall abscess-an uncommon condition treated by an alternative form. Clinics (São Paulo) 2010; 65: 819-21. [PubMed][CrossRef]

4. Kim SB, Oh MJ, Lee SH. Gastric subepithelial lesion complicated with abscess: Case report and literature review. World J Gastroenterol 2015; 21: 6398-403. [PubMed][CrossRef]

5. Ehrenpreis ED. Gastritis. BMJ Best Practice. London: BMJ, 2021. https://bestpractice.bmj.com/topics/en-gb/816/pdf/816/Gastritis.pdf Lest 24.6.2021.

6. Folkehelseinstituttet. Giardiasis - veileder for helsepersonell. Smittevernveilederen. https://www.fhi.no/nettpub/smittevernveilederen/sykdommer-a-a/giardiasis---veileder-for-helsepers/ Lest 24.6.2021.

7. Kiil C, Rosenberg J. Gastric intramural abscess successfully drained during gastroscopy. Gastrointest Endosc 2001; 53: 231-2. [PubMed][CrossRef]

8. Khan M, Leya J, Dhillon S. An unusual case of recurrent gastric abscess. Gastroenterol Hepatol (N Y) 2008; 4: 641-3. [PubMed]

Publisert: 4. januar 2022. Tidsskr Nor Legeforen. DOI: 10.4045/tidsskr.21.0231

Mottatt 22.3.2021, første revisjon innsendt 5.7.2021, godkjent 16.9.2021.

Publisert under åpen tilgang CC BY-ND. Lastet ned fra tidsskriftet.no 26. april 2023. 